DOI: https://doi.org/10.15407/techned2018.04 $=\underline{025}$

\title{
LIMITATION OF APERIODIC TRANSIENT DURATION IN CAPACITORS CIRCUITS OF TWO-CHANNEL ELECTRICAL DISCHARGE INSTALLATIONS
}

Journal

Publisher

ISSN

Issue

Pages
Tekhnichna elektrodynamika

Institute of Electrodynamics National Academy of Science of Ukraine 1607-7970 (print), 2218-1903 (online)

No 4, 2018 (July/August)

$25-28$

\section{Authors}

N.I. Suprunovska ${ }^{1 *}$, V.V. Mykhailenko ${ }^{2 * *}$, Yu.V. Peretyatko ${ }^{2 \star * *}$

1 - Institute of Electrodynamics National Academy of Sciences of Ukraine,

pr. Peremohy, 56, Kyiv, 03057, Ukraine,

e-mail: iednat1@gmail.com

2 - National Technical University of Ukraine "Igor Sikorsky Kyiv Polytechnic Institute",

pr. Peremohy, 37, Kyiv, 03056, Ukraine,

e-mail: VladislavMihailenko@i.ua

* ORCID ID : http://orcid.org/0000-0001-7499-9142

** ORCID ID : http://orcid.org/0000-0003-2793-8966

*** ORCID ID : http://orcid.org/0000-0003-1397-8078

\section{Abstract}

The mathematical modeling of pulse periodic transients in the circuits of capacitors of two-channel semiconductor electrical discharge installations is performed. The conditions for limiting the duration of the aperiodic transient processes of the discharge of capacitors of such 
installation through the electro-spark load, the resistance of which can vary from one discharge to another one, are determined. It is shown that the duration of the aperiodic discharge of the capacitors in two-channel installations depends on the frequency of spark discharge pulses in the load and this duration cannot exceed the duration of spark discharge pulses period. The limitation of the aperiodic discharges duration depends on the parameters of the discharge circuit and the duration of recovery of locking properties of the semiconductor (thyristor) switches. It is shown that reducing the duration of discharge currents in the load increases the frequency and stability of the pulsed modes in the load. References 12, figures 3.

Key words: aperiodic transients, capacitor, semiconductor switch, discharge, pulse current.

Received: 06.03 .2018

Accepted: 12.03.2018

Published:

\section{References}

1. Vovchenko A.I., Tertilov R.V. Synthesis of capacitive non-linear-parametrical energy sources for discharge-pulse technologies. Zbirnyk naukovykh prats Natsionalnoho universytetu korablebuduvannia . 2010. No 4. Pp. 118-124. (Rus)

2. Kravchenko V.I., Petkov A.A. Parametrical synthesis of high-voltage pulse test device with capacitive energy storage. Electrical engineering \& Electromechanics. 2007. No 6. Pp. 70-75. (Rus)

3. Shcherba A.A., Suprunovska N.I., Ivaschenko D.S., Beletsky O.A. Processes of energy exchange between nonlinear and linear links of electric equivalent circuit of supercapacitors. $T$ ekhnichna Elektrodynamika . 2015. No 5. Pp. 3 - 11. (Rus)

4. Shcherba A.A., Suprunovska N.I., Ivaschenko D.S. Modeling of Nonlinear Resistance of 
Electro-Spark Load Taking into Account its Changes During Discharge Current Flowing in the Load and at Zero Current in it. Tekhnichna Elektrodynamika. 2014. No 5. Pp. 23 - 25. (Rus) 5. Livshitz A.L., Otto M.Sh. Pulse electrotechnology. Moskva: Energoatomizdat, 1983. 352 p. (Rus)

6. Nguyen, P.K., Sungho J., Berkowitz A.E. MnBi particles with high energy density made by spark erosion. Journal of Applied Physics. 2014. Vol. 115. No 17. Pp. 17A756-1.

7. Ivanova O.M., Danylenko M.I., Monastyrskyy G.E., Kolomytsev V.I., Koval Y.M., Shcherba A.A., Zakharchenko S.M., Portier R. Investigation of the formation mechanisms for Ti-Ni-Zr-Cu nanopowders fabricated by electrospark erosion method in cryogenic liquids. Metallofizika $i$ Noveishie Tekhnologii . 2009. Vol. 31. No 5. Pp. 603-614.

8. Kokorin V.V., Perekos A.O., Tshcherba A.A., Babiy O.M., Efimova T.V. Intermartensitic phase transitions in Ni-Mn-Ga alloy, magnetic field effect. Journal of Magnetism and Magnetic Materials . 2006. Vol. 302. Issue 1.

Pp. 34-39.

9. Ochin P., Gilchuk A.V., Monastyrsky G.E., Koval Y., Shcherba A.A., Zakharchenko S.N. Martensitic transformation in spark plasma sintered compacts of Ni-Mn-Ga powders prepared by spark erosion method in cryogenic liquids. Materials Science Forum. 2013. Vol. 738-739. Pp.451-455.

10. Shcherba A.A., Podoltsev O.D., Kucheriava I.M., Ushakov V.I. Computer Modeling of Electrothermal Processes and Thermomechanical Stress at Induction Heating of Moving Copper Ingots. Tekhnichna Elektrodynamika. 2013. No 2. Pp. 10-18. (Rus)

11. Shcherba A.A., Kosenkov V.M., Bychkov V.M. Mathematical closed model of electric and magnetic fields in the discharge chamber of an electrohydraulic installation. Surface Engineering and Applied Electrochemistry . 2015. Vol. 51. Issue 6. Pp 581-588.

12. Makarenko M.P., Senko V.I., Yurchenko M.M. System analysis of electromagnetic processes in semiconductor converters of electric power. Kyiv: Institute of electrodynamics of NAN Ukraine, 2005. 241 p. (Ukr) 